\title{
Construction of two ureolytic model organisms for the study of microbially induced calcium carbonate precipitation
}

\section{Authors: James Connolly, Megan Kaufman, Adam Rothman, Rashmi Gupta George Redden, Martin Schuster, Frederick Colwell, \& Robin Gerlach}

NOTICE: this is the author's version of a work that was accepted for publication in Journal of Microbiological Methods. Changes resulting from the publishing process, such as peer review, editing, corrections, structural formatting, and other quality control mechanisms may not be reflected in this document. Changes may have been made to this work since it was submitted for publication. A definitive version was subsequently published in Journal of Microbiological Methods, 94, 3, September 2013. DOI\#10.1016/j.mimet.2013.06.028.

Connolly J, Kaufman M, Rothman A, Gupta R, Redden G, Schuster M, Colwell F, Gerlach R, "Construction of two ureolytic model organisms for the study of microbially induced calcium carbonate precipitation," Journal of Microbiological Methods, September 2013 94(3): 290-299. 


\title{
Construction of two ureolytic model organisms for the study of microbially induced calcium carbonate precipitation
}

\author{
James Connolly ${ }_{b}^{a, b}$, Megan Kaufman c , Adam Rothman a,b, Rashmi Gupta c , \\ George Redden ${ }^{\text {, }}$, Martin Schuster ${ }^{\mathrm{c}}$, Frederick Colwell d, Robin Gerlach a,b,* \\ ${ }^{a}$ Center for Biofilm Engineering, 366 EPS Building, P.O. Box 173980, Montana State University, Bozeman, MT 59717-3980, USA \\ b Department of Chemical and Biological Engineering, 306 Cobleigh Hall, P.O. Box 173920, Montana State University, Bozeman, MT 59717-3920, \\ USA \\ c Department of Microbiology, 220 Nash Hall, Oregon State University, Corvallis, OR 97331, USA \\ d College of Earth, Ocean, and Atmospheric Science, 104 CEOAS Admin Bldg, Oregon State University, Corvallis, OR 97331, USA
}

A B S T R A C T

Two bacterial strains, Pseudomonas aeruginosa MJK1 and Escherichia coli MJK2, were constructed that both express green

fluorescent protein (GFP) and carry out ureolysis. These two novel model organisms are useful for studying bacterial

carbonate mineral precipitation processes and specifically ureolysis-driven microbially induced calcium carbonate precipitation (MICP). The strains were constructed by adding plasmid-borne ure-ase genes (ureABC, ureD and ureFG) to the strains P. aeruginosa AH298 and E. coli AF504gfp, both of which al-ready carried unstable GFP derivatives. The ureolytic activities of the two new strains were compared to the common, non-GFP expressing, model organism Sporosarcina pasteurii in planktonic culture under standard laboratory growth conditions. It was found that the engineered strains exhibited a lower ureolysis rate per cell but were able to grow faster and to a higher population density under the conditions of this study. Both engineered strains were successfully grown as biofilms in capillary flow cell reactors and ureolysis-induced calcium carbonate mineral precipitation was observed microscopically. The undisturbed spatiotem-poral distribution of biomass and calcium carbonate minerals were successfully resolved in 3D using confocal laser scanning microscopy. Observations of this nature were not possible previously because no obligate urease producer that expresses GFP had been available. Future observations

using these organisms will allow researchers to further improve engineered application of MICP as well as study natural mineralization processes in model systems.

\section{N T R O D U C T I O N}

Microbially induced calcium carbonate precipitation (MICP) is an important process in many engineered and natural systems includ-ing: geologic carbon sequestration, radionuclide remediation, soil sta-bilization and permeability manipulation (Cunningham et al., 2013; De Muynck et al., 2010; Ferris et al., 1996; Fujita et al., 2000; Lauchnor et al., 2013; Phillips et al., 2013; Whiffin et al., 2007). Natu-ral systems, including the earth's global carbon cycle and ocean chemistry, have been affected by bacterial precipitation of calcium

carbonate (Riding and Liang, 2005). Microbial carbonate sediments, including those produced by biofilms, are present throughout the geologic record and are widely distributed, making them important for understanding global carbon cycling (Riding, 2000; Vasconcelos et al., 1995). The medical community is also interested in MICP in the context of kidney stones, and mineral formation in ureteral stents and catheters (Morris et al., 1999). Even with the extensive body of literature and interest in MICP, specific mechanisms and implications of how microbes induce mineral formation spatially and temporally are still not clear. For example, the degree to which micron-scale bio-mass and mineral formation alter flow paths that translate to centi-meter and larger scale processes is not fully understood (Armstrong and Ajo-Franklin, 2011; Graf von der Schulenburg et al., 2009).

Perhaps the most highly studied microbial process that can induce calcium carbonate precipitation is ureolysis. Organisms that produce large amounts of urease, such as Sporosarcina pasteurii (formerly known as Bacillus pasteurii (Yoon et al., 2001)), can be extremely ef-ficient at raising the $\mathrm{pH}$ of their environment through hydrolyzing urea and subsequently precipitating calcium carbonate as shown in Eqs. (1)-(4) (Mitchell and Ferris, 2006). 
Urea Hydrolysis:

$\mathrm{CO}\left(\mathrm{NH}_{2}\right)_{2}+2 \mathrm{H}_{2} \mathrm{O} \rightarrow 2 \mathrm{NH}_{3}+\mathrm{H}_{2} \mathrm{CO}_{3}$

Ammonia Protonation and $\mathrm{pH}$ Increase:

$2 \mathrm{NH}_{3}+2 \mathrm{H}_{2} \mathrm{O} \leftrightarrow 2 \mathrm{NH}_{4}^{+}+2 \mathrm{OH}^{-}$

Shift of Carbonate Equilibrium:

$$
\mathrm{H}_{2} \mathrm{CO}_{3}+2 \mathrm{OH}^{-} \leftrightarrow \mathrm{HCO}_{3}^{-}+\mathrm{H}_{2} \mathrm{O}+\mathrm{OH}^{-} \leftrightarrow \mathrm{CO}_{3}^{2-}+2 \mathrm{H}_{2} \mathrm{O}
$$

Calcium Carbonate Precipitation:

$$
\mathrm{CO}_{3}^{2-}+\mathrm{Ca}^{2+} \leftrightarrow \mathrm{CaCO}_{3}(\mathrm{~s})
$$

The urease enzyme hydrolyzes urea $\left(\mathrm{CO}\left(\mathrm{NH}_{2}\right)_{2}\right)$ to produce two ammonia molecules and one carbonic acid molecule (Eq. (1)). The overall effect of urea hydrolysis is a pH increase and a shift of the carbonic acid equilibrium towards carbonate (Eqs. (2) and (3)). In the presence of calcium, or other divalent cations, precipitation of solid carbonate species takes place once a critical saturation state has been reached (Eq. (4)). In engineered systems, calcium is typically supplied to the system so calcium carbonate is most often the primary precipitate. Other organic and inorganic compounds are often incorporated into the precipitates, potentially changing their characteristics from those expected from pure forms of calcium carbonate (Bosak and Newman, 2005).

Microscopic observations have been used extensively to study MICP processes but real-time imaging that can differentiate biomass from mineral precipitates has been a significant challenge. Electron microscopy only provides an end-point view of the system with unavoidable sample preparation artifacts (Dohnalkova et al., 2011). In contrast, light microscopy allows for the direct observation of microorganisms in a fully hydrated environment. Currently, staining is the only way to use light microscopy to definitively differentiate between biomass and the minerals in a hydrated environment (Schultz et al., 2011). However, staining affects biological processes; so long term studies over the course of days using fluorescent stains are not ideal.

The genetic modification of microbes to incorporate a green or other fluorescent protein is a suitable alternative to direct staining (Larrainzar et al., 2005). Organisms that express a fluorescent protein can be imaged over the course of hours and days without the need to introduce potentially inhibitory or toxic stains. Also, expression of the fluorescent protein can potentially be linked to the transcription of a protein of interest thus providing insight into the specific activity of an enzyme.

The goal of this work was to develop bacterial strains that constitutively express green fluorescent protein (GFP) and active urease. This was accomplished through the insertion of plasmid-borne urease genes into bacteria containing a chromosomal gfp insert. In addition to the construction of these organisms, their potential to be used in MICP studies was evaluated based on their ability to hydrolyze urea in batch kinetic studies. The growth and ureolysis kinetics of the newly constructed model organisms were compared to S. pasteurii, a model organism commonly used for MICP studies. Finally, the model organisms' suitability for studies in microscopic flow cells was demonstrated.

\section{Materials and methods}

\subsection{Bacterial strains and growth conditions}

Appropriate growth medium (100 mL, Table 1) was inoculated with $1.0 \mu \mathrm{L}$ per $\mathrm{mL}$ of frozen stock culture. The baffled $250 \mathrm{~mL}$ Erlenmeyer flasks were incubated at the appropriate temperature (Table 1) on horizontal shakers at $200 \mathrm{rpm}$. Cells from overnight cultures were washed twice by centrifugation at $4200 \times g$ and subsequently resuspended in sterile phosphate buffered saline solution (PBS) to remove spent media. PBS had final concentrations of $8.5 \mathrm{~g} / \mathrm{L} \mathrm{NaCl}, 0.61 \mathrm{~g} / \mathrm{L} \mathrm{KH}_{2} \mathrm{PO}_{4}, 0.96 \mathrm{~g} / \mathrm{L}$ $\mathrm{K}_{2} \mathrm{HPO}_{4}$ (all Fisher Scientific, NJ, USA) and was adjusted to a $\mathrm{pH}$ of 7 with concentrated $\mathrm{HCl}$. The final inoculum for all experiments was diluted to an OD of 1.54 (See Section 2.7.1) and inoculated at a volumetric ratio of 1:1000. Experiments were conducted at $37^{\circ} \mathrm{C}$ for Escherichia coli and Pseudomonas aeruginosa strains and $30{ }^{\circ} \mathrm{C}$ for S. pasteurii.

\subsection{Plasmid and model organism construction}

To construct urease-producing strains, P. aeruginosa AH298 (Werner et al., 2004) and E. coli AF504gfp (Folkesson et al., 2008) were both transformed with plasmid pMK001 carrying the urease operon from E. coli DH5 $\alpha$ (pURE14.8) (Collins and Falkow, 1990). The pUC19-based plasmid pURE14.8 carries the urease operon that includes structural genes $u r e A B C$ and putative accessory genes ureD and $u r e F G$ used to acquire nickel (Kim et al., 2006). The full-length sequence of this operon was not previously known (Fig. 2).

Plasmid pMK001 was constructed as follows. To subclone the urease genes, flanking forward and reverse polymerase chain reaction (PCR) primers (Eurofins MWG Operon) were designed with restriction sites PstI and SpeI added to the respective 5' end. Primer sequences can be found in the Supplemental Information. The PCR-amplified fragment was digested with the appropriate restriction enzymes and ligated into an equally-digested pJN105 vector. This plasmid contains an L-arabinose-inducible promoter and encodes for gentamycin resistance (Newman and Fuqua, 1999).

The resulting plasmid construct was used to transform chemically competent $E$. coli cells. Gentamicin-resistant transformants were screened by gel electrophoresis of restriction-digested plasmids. Functional tests for ureolysis were performed in Fluka urea broth (Sigma-Aldrich, MO, USA) containing $100 \mu \mathrm{g} / \mathrm{ml}$ gentamicin and $50 \mathrm{mM}$ L-arabinose (SigmaAldrich). Antibiotic pressure was maintained in all subsequent screening and kinetic experiments to ensure plasmid retention.

Plasmid pMK001 was finally transformed into the strains AH298 and AF504gfp, resulting in strains MJK1 and MJK2, respectively. Both of these strains already contained a mutant, chromosomal $g f p$ variant (Folkesson et al., 2008; Werner et al., 2004). Both GFP variants contain an amino acid sequence at the C-terminal end that is recognized for degradation by proteases within the cell (Andersen et al., 1998).

Table 1

\begin{tabular}{|c|c|c|c|}
\hline Strain & Relevant properties & Growth medium & Reference \\
\hline Pseudomonas aeruginosa AH298 & GFP on chromosome & $\mathrm{LB}^{\mathrm{a}}$ & Werner et al. (2004) \\
\hline Pseudomonas aeruginosa MJK1 & AH298 with urease operon added on pJN105 plasmid & LB plus $100 \mu \mathrm{g} / \mathrm{mL}$ gentamicin & This work \\
\hline Escherichia coli DH5 $\alpha$ (pURE14.8) & $\begin{array}{l}\text { Urease operon on pUC19 plasmid, source of Ure genes for } \\
\text { transformations. }\end{array}$ & LB plus $50 \mu \mathrm{g} / \mathrm{mL}$ ampicillin & Collins and Falkow (1990) \\
\hline Escherichia coli AF504gfp & GFP on chromosome & LB plus $100 \mu \mathrm{g} / \mathrm{mL}$ ampicillin & Folkesson et al. (2008) \\
\hline Escherichia coli MJK2 & AF504gfp with urease operon added on pJN105 plasmid & LB plus $10 \mu \mathrm{g} / \mathrm{mL}$ gentamicin & This work \\
\hline Sporosarcina pasteurii ATCC 11859 & Common urease-positive model organism for MICP studies & $\mathrm{BHI}{ }^{\mathrm{b}}$ plus $20 \mathrm{~g} / \mathrm{L}$ urea or $\mathrm{CMM}-{ }^{\mathrm{c}}$ & Larson and Kallio (1954) \\
\hline
\end{tabular}

Bacterial strains, media and batch growth conditions used in this work.

a $25 \mathrm{~g} /$ L Luria-Bertani Medium.

b $37 \mathrm{~g} / \mathrm{L}$ Brain Heart Infusion Medium.

c Modified Calcite Mineralizing Medium (Ferris et al., 1996) without calcium chloride or sodium bicarbonate and modified to $10 \mathrm{~g} / \mathrm{L}$ urea rather than 20 g/L. 
This causes newly produced GFP to have a short half-life resulting in the disappearance of signal over time unless new GFP is created to replace it (Sternberg et al., 1999). In strain AH298 this altered GFP is linked to the growth rate dependent ribosomal promoter $r r n B p_{1}$ so more active cells produce more GFP for a relative measure of metabolic activity (Werner et al., 2004).

\subsection{Urease gene sequencing}

The urease insert of pMK001 was sequenced in a stepwise manner due to the long sequence length (5594 bp). First, flanking primers (Eurofins MWG Operon, High Purity Salt Free) were used to sequence across the plasmid backbone junction into the insert from either side. This sequence information then allowed for the design of new primers at the ends of the newly sequenced section. Thus, for each of the newly sequenced sections, primers were designed until the sequencing eventually covered the whole insert. The sequencing was conducted by the Center for Genome Research and Biocomputing at Oregon State University on an ABI Prism ${ }^{\circledR} 3730$ Genetic Analyzer using ABI Prism ${ }^{\circledR} 3730$ Data Collection Software v. 3.0 and Prism ${ }^{\circledR}$ DNA Sequencing Analysis Software v. 5.2 and the KB Basecaller algorithm.

\subsection{Test tube screening}

Metabolic screening was performed to ensure that the transformed bacteria were ureolytically active. DH5 $\alpha$ (pURE14.8) was used as a positive control, and the non-transformed strains, AH298 and AF504gfp, were used as negative controls. The screening began by inoculating $15 \mu \mathrm{L}$ of washed cells into $15 \mathrm{~mL}$ of fresh media in $15 \mathrm{~mm} \times 150 \mathrm{~mm}$ $(23.6 \mathrm{~mL})$ glass test tubes in triplicate. The appropriate growth medium for each organism was supplemented with $10 \mathrm{~g} / \mathrm{L}$ urea (Fisher Scientific) and $1 \mu \mathrm{L} / \mathrm{mL}$ phenol red $\mathrm{pH}$ indicator (Sigma). At the concentration used in this study, phenol red turns from clear to bright pink at $\mathrm{pH}$ values greater than approximately 8.2 , which is qualitatively indicative of the $\mathrm{pH}$ increase induced by active urease expression. The time when the media turned pink was used as a measure of relative urease activity between organisms.

\subsection{Batch kinetic studies}

Batch cultures were inoculated in $250 \mathrm{~mL}$ Erlenmeyer flasks with strains MJK1, MJK2 or S. pasteurii for kinetic analysis of urea hydrolysis and population growth. $100 \mathrm{~mL}$ of growth media (see Table 1) was supplemented with $10 \mathrm{~g} / \mathrm{L}$ urea, and flasks were placed on incubated shakers. Samples were taken for a baseline analysis, and the cultures were inoculated. The batch reactors were sampled repeatedly for approximately $30 \mathrm{~h}$. Samples $(1.0 \mathrm{~mL})$ were taken aseptically and placed in $1.5 \mathrm{~mL}$ microcentrifuge tubes. Triplicate $100 \mu \mathrm{L}$ aliquots were transferred into separate wells of a 96 well plate and analyzed for bulk GFP signal and optical density (OD) immediately with the average of the three readings being recorded (see Sections 2.7.1 and 2.7.2). $\mathrm{pH}$ was measured, the sample filtered through a $0.2 \mu \mathrm{m}$ cellulose acetate syringe filter (VWR, NJ, USA) and refrigerated for storage until urea analysis could be performed.

MJK1 and MJK2 were grown in LB medium (see Table 1) with the addition of $10 \mathrm{~g} / \mathrm{L}$ of urea, $50 \mathrm{mM}$-arabinose and $10 \mu \mathrm{M} \mathrm{NiCl}_{2}$ (Fisher Scientific). It was found that $S$. pasteurii does not grow well in LB medium (data not shown) so batch studies were performed in modified calcite mineralization medium (CMM) after Ferris et al. (1996) by omitting calcium chloride and sodium bicarbonate (CMM["CMM minus"]) as well as adjusting the urea concentration to $10 \mathrm{~g} /$ L. S. pasteurii starter cultures from frozen stocks were grown in BHI medium (Sigma-Aldrich) containing $20 \mathrm{~g} / \mathrm{L}$ urea.

\subsection{Confocal microscopy}

Confocal microscopy of mature biofilms in capillary flow cell reactors was performed to demonstrate the use of the newly constructed model organisms in MICP experiments. Borosilicate glass capillary flow cells with a $0.9 \mathrm{~mm} \times 0.9 \mathrm{~mm}$ square cross section and an approximate length of $10 \mathrm{~cm}$ had a wall thickness of $0.17 \mathrm{~mm}$ (F\&D Glass, NJ, USA). Capillaries were imaged with a Leica DM6000 CS confocal laser scanning microscope (CLSM). Growth media (per Table 1) were infused into capillaries with a calibrated syringe pump connected with size 14 silicone tubing.

Autoclaved capillaries were injected with cell inoculum (per Section 2.1) and incubated statically for 2 h to allow for cell attachment. Flow was initiated and maintained at $0.5 \mathrm{~mL} / \mathrm{h}$ for four days at which point biofilm colonies were clearly visible. Capillaries were mounted on the microscope stage and the medium was switched to $\mathrm{CMM}$ (containing $\mathrm{CaCl}_{2}$ ) supplemented with the required antibiotic, $50 \mathrm{mM}$ L-arabinose and $10 \mu \mathrm{M} \mathrm{NiCl}_{2}$.

Biofilm colonies were located and 3D confocal stacks were collected repeatedly over the course of the observation time. Images presented in this work were collected through a Leica HC PL FLUOTAR $10 \times / 0.30$ dry objective. GFP fluorescence was imaged with excitation from a $488 \mathrm{~nm}$ laser and detection between 498 and $700 \mathrm{~nm}$. Precipitates were imaged by detecting reflected $488 \mathrm{~nm}$ laser light between 483 and $493 \mathrm{~nm}$. Raw CLSM data were processed with Imaris Version 7.6 (Bitplane, Zurich, $\mathrm{CH}$ ). All confocal slices collected in 3D were projected onto one image for each time point. This projection provides a view of the sample as though the observer is looking at the specimen from the top.

\subsection{Analytical measurements}

\subsubsection{Biomass quantification}

The optical density (OD) measured at $600 \mathrm{~nm}$ was used to quantify the turbidity of liquid cultures as a comparative measure of cell density. Triplicate $100 \mu \mathrm{L}$ samples were added to separate wells in a polycarbonate 96 well plate and absorbance of $600 \mathrm{~nm}$ light was measured by a BioTek Instuments (Winooski, VT, USA) Synergy HT Multi-Mode Microplate Reader and the data were analyzed using Gen5 software. All readings are presented as deviations from the initial time point just before inoculation, or in the case of the inoculum OD to the phosphate-buffered saline solution absorbance. The 96 well plate method results in a light path length of $0.26 \mathrm{~cm}$, so for increased relevance to literature values, the $\mathrm{OD}$ values presented herein were adjusted to a standard path length of $1.0 \mathrm{~cm}$ using the Beer-Lambert relationship (Anderson et al., 2004).

\subsubsection{Bulk GFP}

Total culture GFP florescence (bulk GFP) was measured with excitation from a tungsten halogen light source at 485/20 nm and intensity measured through a 528/20 nm band pass filter using a BioTek Instruments Synergy HT Multi-Mode Microplate Reader (Winooski, VT, USA). The bulk GFP measurements represent the total amount of GFP present in the culture at each time point. Values for GFP are reported in arbitrary fluorescence units relative to the autofluorescence of fresh growth medium.

\subsubsection{Urea}

Urea was analyzed by high pressure liquid chromatography (HPLC) after $0.2 \mu \mathrm{m}$ filtration and dilution to within the calibration range of 10-100 mg/L urea (Clark et al., 2007). Urea was derivatized with xanthydrol under acidic conditions to produce a diode array detectable compound at $230 \mathrm{~nm}$. Samples were introduced to a $4.6 \times 150 \mathrm{~mm}$ Agilent Zorbax Eclipse XDB-18 analytical column in an Agilent 1100 Series HPLC (Agilent Technologies Inc.) and eluted with a gradient of $20 \mathrm{mM}$ ACS grade sodium acetate (Sigma-Aldrich) and HPLC grade acetonitrile (Fisher Scientific). Peak areas were measured (urea peak at approximately $10.5 \mathrm{~min}$ ) using Agilent ChemStation software (Rev.A.10.02) and compared to calibration standards. 


\subsection{4. $\mathrm{pH}$}

The $\mathrm{pH}$ values of batch cultures were measured using a VWR sympHony meter and a Denver Instruments, Micro Glass-body pH electrode with a $5 \mathrm{~mm}$ diameter body. $\mathrm{pH}$ values were measured in $0.7 \mathrm{~mL}$ samples in $1.5 \mathrm{~mL}$ microcentrifuge tubes after the probe was calibrated using pH 7 and 10 buffers.

\subsection{Kinetic models}

Kinetic rate parameters were established by fitting the experimental results of the batch kinetic studies to models by minimizing the sum of the squared errors between the model and observations. A solution that minimizes the sum of the squared errors was found using the generalized reduced gradient (GRG) nonlinear optimization technique (Lasdon et al., 1978). A Gompertz function (Eq. (5)) was chosen to be applied to the population data in the form presented by Zwietering et al. (Gompertz, 1825; Zwietering et al., 1990).

$\ln \left(\frac{\mathrm{OD}}{\mathrm{OD}_{o}}\right)=A \exp \left[-\exp \left[\frac{\mu_{\max } \exp (1)}{\mathrm{A}}(\lambda-t)+1\right]\right]$

$\mathrm{OD}$ is the optical density at time $(\mathrm{t}), \mathrm{OD}_{\mathrm{o}}$ is the initial optical density, $\mu_{\max }$ is the specific growth rate during exponential growth, $\lambda$ is the lag time and $\mathrm{A}$ is equal to $\ln \left(\mathrm{OD}_{\mathrm{st}} / \mathrm{OD}_{\mathrm{o}}\right)$. $\mathrm{OD}_{\mathrm{st}}$ is the optical density at steady state, or in this case $\mathrm{OD}_{\text {st }}$ was taken to be the maximum OD reached by the culture. OD is the measure of population density throughout this work. The fitted parameters for the population model are $\mu_{\max }$ and $\lambda$. The decrease of OD associated with population decay was not taken into account in this study.

Urea concentration was modeled in three different ways based on techniques from the literature. The general form of the ureolysis model is

$\frac{\mathrm{dC}}{\mathrm{dt}}=\mathrm{f}(\mathrm{C}) \cdot \mathrm{OD} \cdot \mathrm{C}^{\mathrm{n}}$

Where $C$ is the concentration of urea at time $(t), f(C)$ is a function of $\mathrm{C}$ and $\mathrm{n}$ is a constant describing the reaction order. The rate is scaled by the optical density at time $(t)$ as a measure of the amount of urease present in the reactor.

The simplest ureolysis model is represented with $f(C)=-r_{0}$ and $\mathrm{n}=0$. This is referred to as the zero order model where

$\frac{\mathrm{dC}}{\mathrm{dt}}=-\mathrm{r}_{\mathrm{o}} \cdot \mathrm{OD}$

The zero-order model is correctly applied to systems with an excess of urea, or other substrates, where the enzyme is working at a constant maximum rate. The zero-order model is easily solved analytically so its use in complicated models where other processes are taking place is common. $\mathrm{dC} / \mathrm{dt}$ does not depend on $\mathrm{C}$, so the same ureolysis rate occurs independently of time and concentration. $r_{0}$, the zero order rate coefficient, is the fitted parameter in the zero-order model.

The most common ureolysis model in the literature is where $\mathrm{f}(\mathrm{C})=-\mathrm{k}_{1}$ and $\mathrm{n}=1$ so the reaction rate is linearly dependent on concentration. Here we will refer to this model as first order and the following equation applies.

$\frac{\mathrm{dC}}{\mathrm{dt}}=-\mathrm{k}_{1} \cdot \mathrm{OD} \cdot \mathrm{C}$

First order rate models are commonly applied to ureolysis driven calcium carbonate precipitation work (Ferris et al., 2003; Tobler et al., 2011; Zhang and Klapper, 2010), however, only Zhang and Klapper (2010) scale the ureolysis rate to population density as done in this work. The first order rate coefficient, $\mathrm{k}_{1}$, was fitted to the observed data in the first order model.

The last model that was applied is a Michaelis-Menten (M-M) function where $\mathrm{n}=1$ and $\mathrm{f}(\mathrm{C})=-\mathrm{V}_{\max } /\left(\mathrm{k}_{\mathrm{m}}+\mathrm{C}\right)$. $\mathrm{V}_{\max }$ is the maximum reaction velocity and $\mathrm{k}_{\mathrm{m}}$ is the half saturation coefficient.

$\frac{\mathrm{dC}}{\mathrm{dt}}=\frac{\mathrm{V}_{\max }}{\mathrm{k}_{\mathrm{m}}+\mathrm{C}} \cdot \mathrm{OD} \cdot \mathrm{C}$

M-M models are common for the description of enzyme kinetics in general and have been widely applied to urease and other pure enzymes as well as to systems with ureolytic bacteria (Bachmeier et al., 2002; Benini et al., 1996; Ciurli et al., 1996; Stocks-Fischer et al., 1999). By using a M-M type expression a more accurate representation of the concentration dependence on the reaction rate is derived. At high concentrations, the reaction rate asymptotically approaches a maximum $\left(\mathrm{V}_{\max }\right)$ and as the urea concentration approaches zero so does the reaction rate. Other, more complex ureolysis models that include $\mathrm{pH}$ dependence, ammonium inhibition and temperature relationships have been proposed (Fidaleo and Lavecchia, 2003). More complex models were not used in this work because the large number of fitting parameters require more focused experimentation outside of the scope of this work.

The population growth model is assumed to be independent of the ureolysis models but the ureolysis models are scaled by the population density. As a result, first the Gompertz population growth model was fitted to the experimental optical density data independently of the ureolysis models. The resulting growth curve was then used to estimate ureolysis rate coefficients from experimental data from the same experiment.

\section{Results and discussion}

\subsection{Construction of urease positive GFP organisms}

Two urease-positive GFP-expressing bacteria were successfully constructed and named $P$. aeruginosa strain MJK1 and E. coli strain MJK2. The initial GFP containing organisms were P. aeruginosa AH298 (Werner et al., 2004) and E. coli AF504gfp (Folkesson et al., 2008), respectively. The previously cloned urease operon from $E$. coli DH5 $\alpha$ (pURE14.8) was inserted into the L-arabinose-inducible plasmid pJN105 and subsequently renamed pMK001. The pMK001 plasmid was introduced into the GFP strains (Fig. 1). The urease insert portion of pMK001 was sequenced and compared to the previously sequenced regions that cover the ureDABC and ureFG in DH5 $\alpha$ (pURE14.8). The sequence between ureDABC and ureFG is not known from previous work and cannot be compared for homology. The DH5 $\alpha$ (pURE14.8) ureDABC sequence (D'Orazio and Collins, 1993) was found to be identical to the corresponding sequence in pMK001. However, according to the basecalling algorithm used to determine the sequence (KB Basecaller), the insert had two additional nucleotides included near the end of ureFG (see supplemental materials). When analyzed with an older version of KB Basecaller (3730pop7LR) the two ureFG segments were identical. An NCBI BLAST search of the entire insert region, including insertions, showed segments with high similarity to a Proteus mirabilis urease operon (Query cover: 48\% E value: 0.0 ) and Vibrio fischeri ES114 chromosome I (Query cover: 43\% E value: 0.0). The same BLAST search without the insertions yielded similar results with only the query coverage being reduced slightly. Sequences with and without the insertions were loaded into the NCBI ORF Finder and the insertions were found to have no effect in the predicted open reading frames of the insert. All predicted open reading frames occur before the insertions.

The ureFG nucleotide insertions are likely due to PCR amplification errors. These insertions may be significant because $u r e F G$ genes are believed to be involved in acquiring nickel (Kim et al., 2006) and 


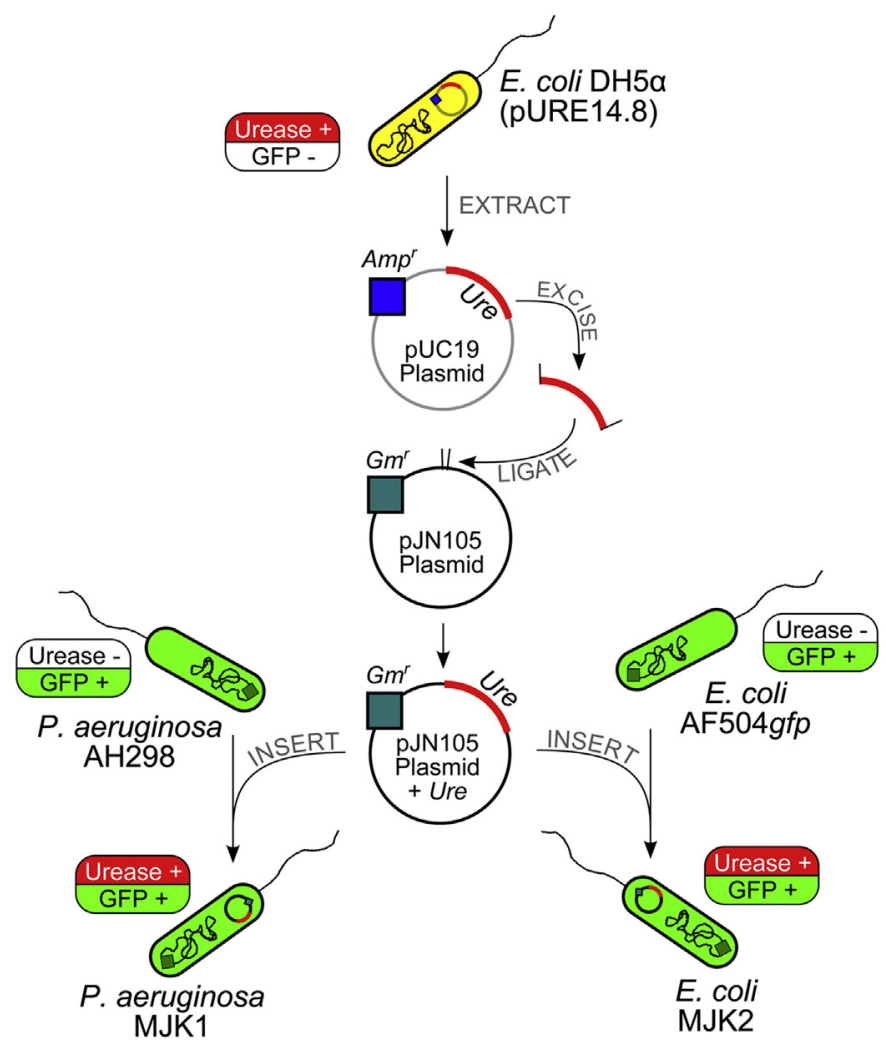

Fig. 1. P. aeruginosa MJK1 and E. coli MJK2 were constructed by excising the urease operon (Ure) from the pUC19 plasmid previously contained in E. coli DH5 $\alpha$ (pURE14.8). The urease operon was ligated into plasmid pJN105 to construct plasmid pMK001, which was then transferred to P. aeruginosa AH298 and E. coli AF504gfp. The resulting bacterial strains, MJK1 and MJK2, respectively, express both active urease and constitutive GFP. Amp ${ }^{\mathrm{r}}$ and $\mathrm{Gm}^{\mathrm{r}}$ refer to ampicillin and gentamicin resistance genes, respectively.

we have shown that both transformed organisms require supplemental nickel to express significant urease activity (see Table 2). There are two possible effects of these insertions. One explanation is that the nickel acquisition genes are somehow incompatible with the organisms into which they have been inserted. The gene is present but potentially not synthesized in a suitable form to function in the context of the native metabolic framework. If this was the case, and the ureFG genes were incompatible with the transformant strains, it seems likely that both DH5 $\alpha$ (pURE14.8) and MJK2 would exhibit the same behavior towards nickel because they are of the same species. However, these two strains do not behave the same in the presence of nickel (Table 2). A more likely explanation is that these insertions caused a translational difference that was large enough to
Table 2

Response of different cultures to nickel addition as determined by the relative ability to increase $\mathrm{pH}$ in urea broth. Response was determined by measuring the period of time required for the color change reaction to occur in the respective cultures.

\begin{tabular}{llll}
\hline Strain & & $\begin{array}{l}\text { No Supplemental } \\
\text { Nickel }\end{array}$ & $\begin{array}{l}10 \mu \mathrm{M} \\
\mathrm{NiCl}_{2}\end{array}$ \\
\hline $\begin{array}{lll}\text { E. coli } \\
\text { DH5 } \alpha \text { (pURE14.8) }\end{array}$ & Positive control & +++ & +++ \\
$\begin{array}{l}\text { P. aeruginosa } \\
\text { AH298 }\end{array}$ & Untransformed negative control & + & + \\
E. coli AF504gfp & Untransformed negative control & - & - \\
P. aeruginosa MJK1 & New construct & + & +++ \\
E. coli MJK2 & New construct & - & ++ \\
\hline
\end{tabular}

Phenol red color change within $(10 \mathrm{~h}:+++)(12 \mathrm{~h}:++)(24 \mathrm{~h}:+)$ (No activity: -$)$

render nickel acquisition nonfunctional. Based on our data, this seems possible because ureolytic activity in MJK2 was highly dependent on the addition of supplemental nickel (Table 2) while DH5 $\alpha$ (pURE14.8) was unaffected by nickel addition.

\subsection{Test tube screening}

Transformed strains were screened for ureolytic activity using the phenol red test tube assay. The screening showed positive results for ureolysis in both transformed strains. Non-transformed strains did not exhibit significant ureolysis (see Table 2). L-arabinose, at a concentration of $50 \mathrm{mM}$, increased the level of urease activity as expected based on plasmid construction (data not shown).

It became evident during preliminary screenings that the addition of nickel is important for the transformed strains to show ureolytic activity. We found that the positive control organism from which urease was extracted, DH5 $\alpha$ (pURE14.8), did not require supplemental nickel, whereas the new transformants, MJK1 and MJK2, required additional nickel for urease activity. The addition of $10 \mu \mathrm{M} \mathrm{NiCl}_{2}$ improved the ability of strains MJK1 and MJK2 to raise the pH similarly to DH5 $\alpha$ (pURE14.8). Nickel concentrations of up to $10 \mu \mathrm{M}$ did not appear to affect the ability for DH5 $\alpha$ (pURE14.8) to increase pH.S. pasteurii was not used as a positive control for the initial screening because of differing optimal growth conditions. It is well understood that $S$. pasteurii is highly ureolytically active; however, its population growth characteristics are much different than both $E$. coli and $P$. aeruginosa species making DH5 $\alpha$ (pURE14.8) the better positive control for screening purposes.

The activity of urease has been reported to be dependent on nickel concentration (Mobley and Hausinger 1989; Mobley et al., 1995; Benini et al., 1999). The particularly strong nickel dependence in MJK2 has the potential to be utilized as an experimental control in future work, potentially allowing researchers to manipulate ureolysis and growth rates independently.

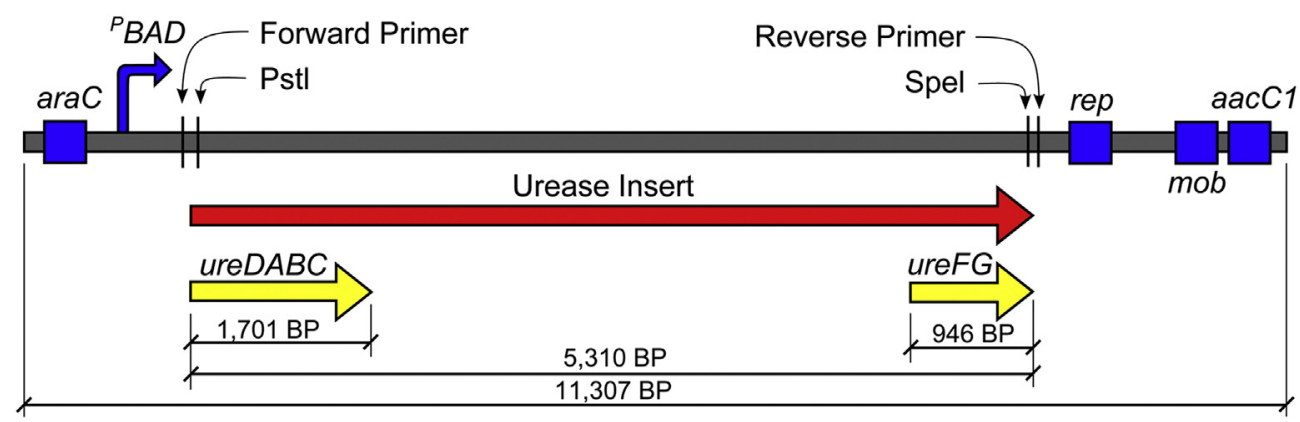

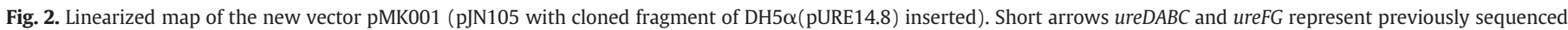

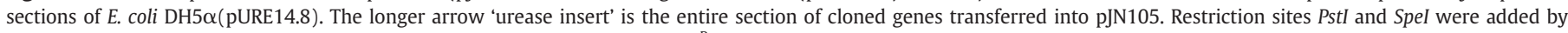

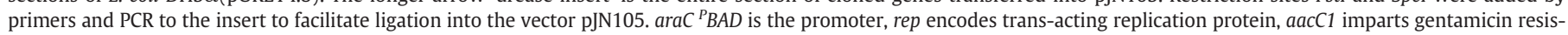
tance, mob encodes the plasmid mobilization functions. 
Although nickel is required for bacterial growth (normally in nanomolar concentrations) micro- or millimolar levels can be toxic to cells (Sar et al., 1998). Supplemental nickel has been added to media for ureolytically constructed organisms in the past. For instance, Zhang et al. found that their recombinant urease strain of Lactococcus lactis exhibited the maximum level of urease activity at $250 \mu \mathrm{M} \mathrm{NiSO}_{4}$. They also reported from the literature that a range of supplemental nickel (from $2.5 \mu \mathrm{M}$ to $200 \mu \mathrm{M}$ ) has been added to media for growing other urease constructs (Zhang et al., 2009). The $10 \mu \mathrm{M}$ nickel tested for the transformants created in this work fits within that range.

\subsection{Kinetic studies}

\subsubsection{Growth and ureolysis characteristics}

Both transformed organisms express measurable urease activity under the conditions tested as demonstrated through a decrease in urea concentrations, and a corresponding increase in $\mathrm{pH}$, OD and bulk GFP signal in batch cultures over time (Fig. 3). Urea concentrations decreased to less than $1 \%$ of the initial concentration of $10 \mathrm{~g} / \mathrm{L}$ $30 \mathrm{~h}$ after inoculation in the presence of strains MJK1, MJK2 or S. pasteurii. The transformants began hydrolyzing urea noticeably earlier than S. pasteurii, which is attributed to differing lag times. Both transformants showed GFP expression that generally followed the trends in population growth.

The GFP profile during batch growth reveals two differences between the transformants (Fig. 3,B). While GFP fluorescence for each of the transformants reaches a maximum very near the time of maximum OD and decays thereafter, the GFP fluorescence for MJK2 decreases more slowly. The faster decrease in GFP fluorescence for MJK1 is expected because of the growth rate dependence of GFP production through control by the growth rate-dependent $r r n B p_{1}$ ribosomal promoter.
Despite a significantly longer lag phase, $S$. pasteurii affected the $\mathrm{pH}$ such that a maximum was reached over a similar period of time as for both of the transformants. The $S$. pasteurii $\mathrm{pH}$ curve has a different shape than for both of the transformants. CMM- has less buffering capacity than LB between $\mathrm{pH} 6$ and 8 (titration data not shown) which explains the difference in the shape of the $S$. pasteurii $\mathrm{pH}$ curve. The maximum $\mathrm{pH}$ reached by MJK1 was the highest at $9.31 \pm 0.01$ followed by S. pasteurii at $9.24 \pm 0.02$ and MJK2 at $9.18 \pm 0.08( \pm$ is the $95 \%$ confidence interval). Direct comparative conclusions cannot be made about urea hydrolysis based solely on $\mathrm{pH}$ because S. pasteurii was grown in a different medium. Rather, OD and urea concentration are the primary parameters of interest in this work.

\subsubsection{Kinetic curve fitting}

Kinetic parameters were estimated by fitting the zero, first, and Michaelis-Menten order models to experimental data for both transformed organisms and S. pasteurii. MJK2 grew the fastest and had the shortest lag time while $S$. pasteurii exhibited the slowest growth and longest lag time Fig. 4; Table 3). Fitted parameters from all three ureolysis models show that, on an OD-normalized basis, S. pasteurii is most efficient at hydrolyzing urea. I.e. the cell specific ureolytic activity is the highest for $S$. pasteurii.

The population growth model fit the data well from inoculation through exponential phases. However, the fit became poor as OD decreased during the stationary phase because there is no decay built into the Gompertz model. This poor fit during stationary phase is acceptable in the context of this work though because the goal was to compare the ureolysis characteristics of the three different strains during the exponential growth phase. Most ureolysis occurs before stationary phase is reached, thus the poor fit at later time points does not significantly affect the results of the ureolysis models.

Zero, first, and $\mathrm{M}-\mathrm{M}$ order models fit the data at an $\mathrm{R}^{2}>0.95$ (Table 3). Parameter estimation for the first and zero order model
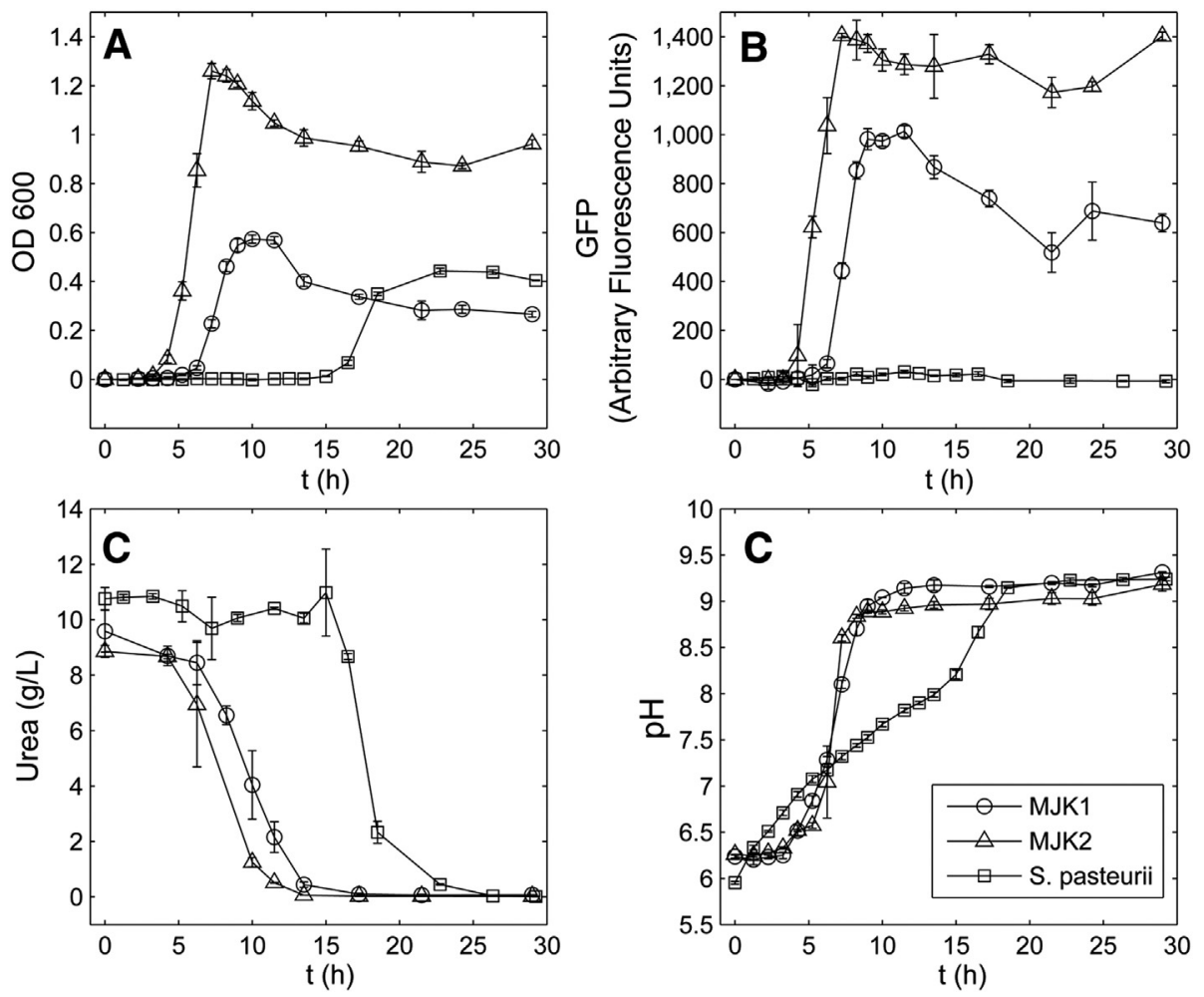

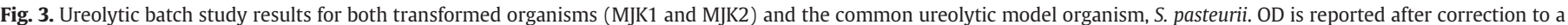

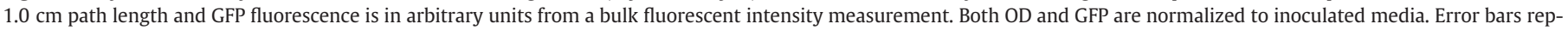

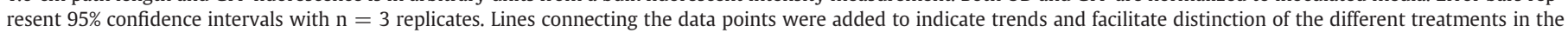
graphs. 

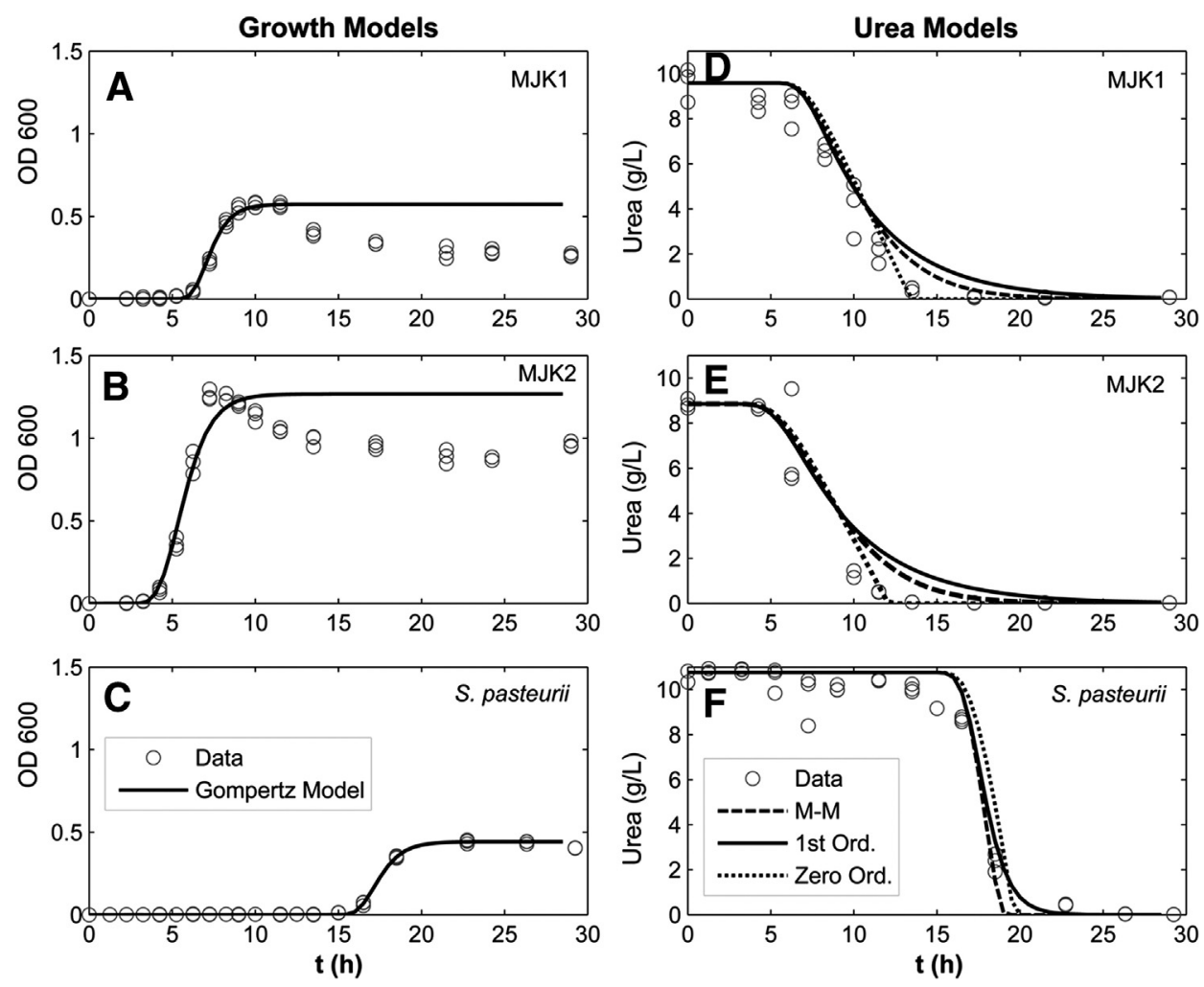

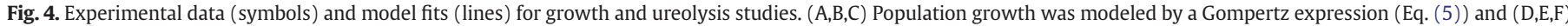
ureolysis rates were modeled using Michaelis-Menten (M-M), first order, and zero order rate models (Eqs. (7), (8) and (9)).

was highly reproducible with the relative standard deviation of estimates from triplicate treatments being $\leq 7.7 \%$. A larger relative standard deviation was observed with the M-M model at $27.4 \%$ for $\mathrm{k}_{\mathrm{m}}$ and $18.9 \%$ for $\mathrm{V}_{\max }$. The $\mathrm{M}-\mathrm{M}$ model has more degrees of freedom thus allowing for more variation in the fitted $\mathrm{V}_{\max }$ and $\mathrm{k}_{\mathrm{m}}$ and resulting in a larger deviation of fitted parameters as compared to both of the one-parameter models.

\subsubsection{Strain comparison}

MJK1 exhibited a higher specific ureolysis rate, i.e. a higher ureolysis rate per cell; however, MJK2 had a higher specific growth rate resulting in more rapid ureolysis in MJK2 cultures. A number of possibilities may explain these rate differences. $\mathrm{pH}$ and ammonium concentration are known to affect urease activity of the pure enzyme (Fidaleo and Lavecchia, 2003). E. coli and P. aeruginosa species are also known to regulate cytoplasmic and extracellular pH differently. In E. coli, cytoplasmic and extracellular $\mathrm{pH}$ remain approximately equal when the culture $\mathrm{pH}$ is disturbed over a range between approximately pH 6.0 and 7.5 (Wilks and Slonczewski, 2007). To the authors' knowledge, no similar measurement of cytoplasmic $\mathrm{pH}$ has been performed for any P. aeruginosa strains but it is likely that $\mathrm{pH}$ regulation is different due to differing efflux pumps, transporters and metabolic potential.

Native metabolic processes in the transformants may play an important role in their ureolysis kinetics. Many P. aeruginosa strains possess urease genes. Currently, all four of the sequenced $P$. aeruginosa strains in the MetaCyc database (Caspi et al., 2012) are annotated for urease structural genes, ure $A B C$, and multiple accessory genes. However, native urease in $P$. aeruginosa is thought to be highly regulated. Early ureolysis studies in Pseudomonads even wrongly concluded that all species within the genus Pseudomonas were urease negative (Stewart, 1965). In our own work we were unable to establish growth conditions for $P$. aeruginosa strains that would permit

Table 3

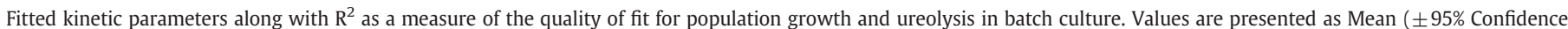
Interval) with $\mathrm{n}=3$ replicates.

\begin{tabular}{|c|c|c|c|c|c|c|c|c|c|}
\hline \multicolumn{10}{|c|}{ Population growth model (Gompertz) } \\
\hline Parameter & Unit & MJK1 & $R^{2}$ & MJK2 & & $R^{2}$ & & S. pasteurii & $R^{2}$ \\
\hline$\mu_{\max }$ & $1 / \mathrm{h}$ & $0.21( \pm 0.01)$ & \multirow{3}{*}{$0.37^{\mathrm{a}}$} & \multicolumn{2}{|c|}{$0.29( \pm 0.03)$} & \multicolumn{4}{|c|}{$0.15( \pm 0.01)$} \\
\hline$\gamma$ & $\mathrm{h}$ & $6.12( \pm 0.06)$ & & \multicolumn{2}{|c|}{$3.97( \pm 0.08)$} & \multirow[t]{2}{*}{$0.89^{\mathrm{a}}$} & & $16.08( \pm 0.10)$ & \multirow[t]{2}{*}{0.99} \\
\hline $\mathrm{OD}_{\max }$ & OD & $0.57( \pm 0.02)$ & & 1.27 & & & & $0.44( \pm 0.01)$ & \\
\hline \multicolumn{10}{|c|}{ Urea models } \\
\hline Model & Parameter & Unit & MJK1 & $R^{2}$ & MJK2 & & $R^{2}$ & S. pasteurii & $R^{2}$ \\
\hline \multirow[t]{2}{*}{ M-M } & $\mathrm{V}_{\max }$ & $\mathrm{g} \mathrm{L}^{-1} \mathrm{OD}^{-1} \mathrm{~h}^{-1}$ & $7.0( \pm 3.2)$ & \multirow[t]{2}{*}{0.97} & \multicolumn{2}{|l|}{$2.5( \pm 0.8)$} & 0.97 & $28.4( \pm 2.8)$ & \multirow[t]{2}{*}{0.96} \\
\hline & $\mathrm{k}_{\mathrm{m}}$ & $\mathrm{g} / \mathrm{L}$ & $10.6( \pm 7.6)$ & & \multicolumn{2}{|l|}{$8.4( \pm 4.0)$} & & $4.4( \pm 0.1)$ & \\
\hline 1st order & $\mathrm{k}_{1}$ & $\mathrm{OD}^{-1} \mathrm{~h}^{-1}$ & $0.40( \pm 0.06)$ & 0.96 & \multicolumn{2}{|l|}{$0.17( \pm 0.01)$} & 0.96 & $1.88( \pm 0.15)$ & 0.96 \\
\hline Zero order & $r_{0}$ & $\mathrm{~g} \mathrm{~L}^{-1} \mathrm{OD}^{-1} \mathrm{~h}^{-1}$ & $2.69( \pm 0.64)$ & 0.96 & \multicolumn{2}{|l|}{$1.09( \pm 0.09)$} & 0.97 & $10.66( \pm 0.76)$ & 0.97 \\
\hline
\end{tabular}

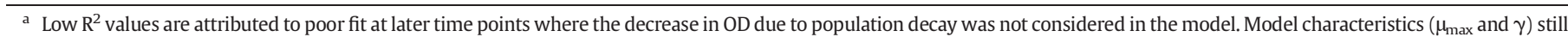
represent the data adequately for the purposes of this comparative study despite the low $\mathrm{R}^{2}$ value. See Fig. $4 \mathrm{~A}$ and $\mathrm{B}$ for a graphical representation of the model fit. 
expression of significant ureolysis activity (data not shown). It is known that $P$. aeruginosa strains possess a urea uptake system that is suppressed by the presence of ammonium (Jahns, 1992). E. coli is not known to have a similar urea uptake system. Subsequent work by Jahns showed that ATP generation was linked to urea hydrolysis in S. pasteurii by cytosolic urease contributing to the membrane potential with cytosol alkalinization and ammonium efflux thought to be the important factors (Jahns, 1996). The mechanism discussed by Jahns (1996) explains the high urease activity in S. pasteurii but it could also be argued that some of the same mechanisms allow MJK1 to be more efficient at ureolysis than the E. coli strain MJK2 on a population normalized basis.

\subsubsection{Additional parameters}

Other factors that influence the kinetics of the urease enzyme are $\mathrm{pH}$, ammonium concentration and temperature. Fidaleo and Lavecchia (2003) constructed a detailed model taking all known major factors into account using purified jack bean urease. Although the Fidaleo and Lavecchia model describes a pure enzyme system very well, constants from the literature for pure enzyme systems do not necessarily apply to systems with microorganisms. The Fidaleo and Lavecchia model was fit to the data with slight modification to scale the rate to OD rather than enzyme concentration and it was found to be a poor fit with the published $\mathrm{pH}$, temperature and product inhibition constants (data not shown). The data collected for this study was not sufficient for the estimation of the large number of parameters associated with such a complex enzyme kinetic model

\subsection{Application in flow cell reactors}

MJK1 and MJK2 are clearly ureolytically active and express GFP under the growth conditions provided during this study but the formation of biofilm must also be considered in order for these strains to be successfully used in the study of MICP. Biofilm formation is an important attribute because it is thought that extracellular biofilm components play an important role in crystal nucleation and calcium carbonate polymorphology (Decho, 2010; Ercole et al., 2012; Rodriguez-Navarro et al., 2007). Preliminary flow-through experiments conducted in $1 \mathrm{~mm}$ square glass capillary tubes under continuous laminar flow indicated that both transformants produce thick biofilms and precipitate calcium carbonate. The biofilm characteristics are different between the two transformants with MJK1 forming dense colony biofilms and MJK2 forming a more unstructured, flexible biofilm. In both cases, biomass and minerals were successfully imaged with CLSM. Fig. 5 shows MJK1 in a time series of mineral formation associated with a biofilm colony in a square capillary flow cell.
Experiments using either MJK1 or MJK2 in flow cells will have to be designed carefully in order to promote and sustain the appropriate metabolism. Both transformants are capable of using metabolic pathways that could potentially counteract the $\mathrm{pH}$ increase associated with ureolysis making mineral precipitation impossible even with high ureolytic activity. One example would be if oxygen was depleted in an experimental system and acid-producing fermentation pathways were being utilized. At some point urease might be too inhibited by the low $\mathrm{pH}$ values to show significant activity. In addition, even if a low pH-tolerant urease variant is produced, low $\mathrm{pH}$ values (often resulting in low saturation indices) might make precipitation not possible and possibly even cause dissolution of previously precipitated calcium carbonate. Metabolic heterogeneities in biofilm systems could also create multiple environments within an experiment, making results more difficult to interpret.

\section{Conclusions}

Two novel model organisms were constructed to conduct pore scale ureolysis-driven MICP experiments, where organism and mineral growth can be visualized continuously and non-invasively. The two new bacterial strains will allow for the research of spatiotemporal physical and biochemical phenomena at the micrometer scale in MICP systems. Previously, it was not possible to observe the spatiotemporal orientation of biomass with respect to newly formed precipitates that were induced by the same biomass. The new strains allow for the visualization of biomass in situ without the need for fluorescent staining. The ability to study MICP in this way can be used for the optimization of engineered applications and for the development of an improved fundamental understanding of natural microbial precipitation processes.

Kinetic analysis revealed that the specific ureolytic activity of MJK1 and MJK2 is not as high as for S. pasteurii, the most common organism used for MICP experiments. Analysis of batch cultures revealed that all commonly used kinetic models can be fit to the experimental data with limited deviation. The zero order (constant ureolysis rate) model is simple and describes the data well in all cases when its rate is normalized to the population density. The population density was modeled with a Gompertz function, fitting a lag time and maximum specific growth rate to the optical density data. MJK2 exhibited the fastest growth characteristics; however, the other two organisms (MJK1 and S. pasteurii) exhibited higher specific (i.e. cell number normalized) ureolysis rates.

Differences in specific growth and ureolysis rates, along with physiological differences, make the potential use of each of the new model organisms unique. The newly constructed strains require supplemental nickel for ureolysis activity. MJK2 urease is particularly well controlled with nickel, introducing a potentially useful system

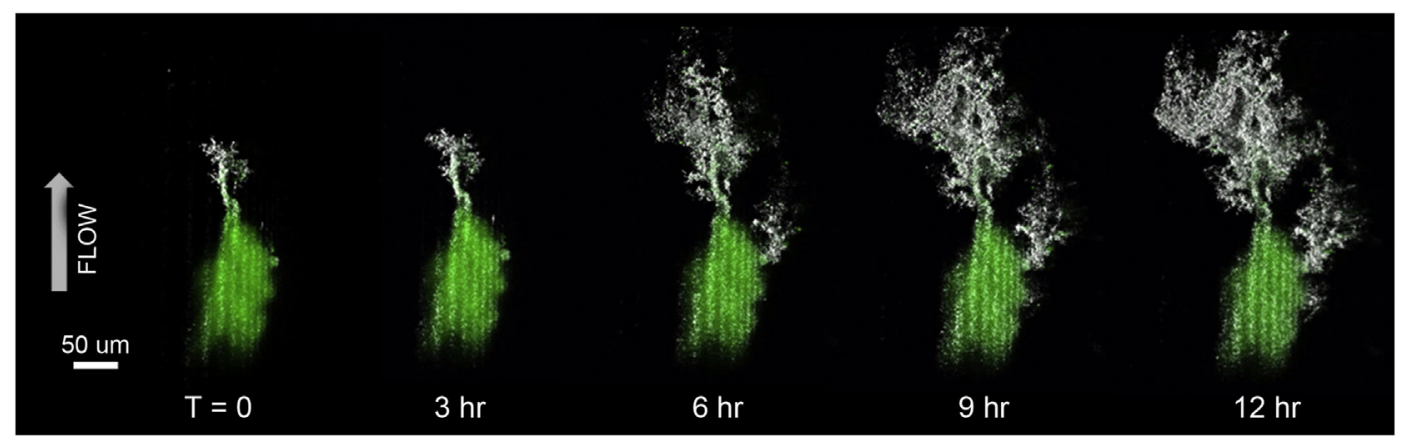

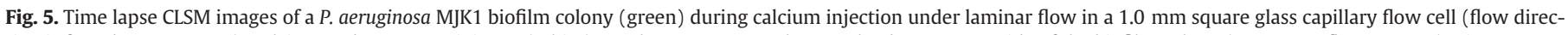

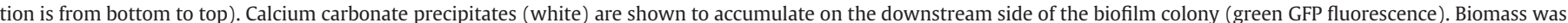

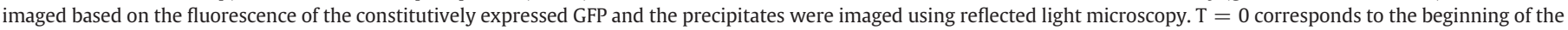

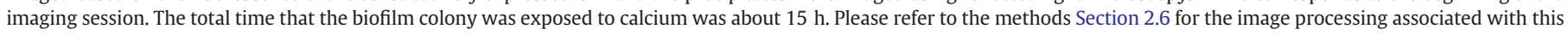
figure. 
control where ureolysis activity could be regulated independently of growth. The two chromosomal GFP constructs behave differently as well. GFP expression of MJK1 is more closely associated with metabolic activity through its control under the growth rate dependent ribosomal promoter $r r n B p_{1}$ while MJK2 constitutively expresses GFP. MJK1 will be of more use in studies aimed at determining the spatially resolved metabolic activity whereas MJK2 may be preferred in studies where only the physical location of biomass is important.

\section{Glossary}

$\begin{array}{ll}\text { A } & \ln \left(\mathrm{OD}_{\mathrm{st}} / \mathrm{OD}_{\mathrm{o}}\right) \\ \mathrm{C} & \text { Urea concentration } \\ \mathrm{CMM} & \text { Calcite Mineralizing Medium } \\ \mathrm{GFP} & \text { Green Fluorescent Protein } \\ \mathrm{HPLC} & \text { High Pressure Liquid Chromatography } \\ \mathrm{k}_{\mathrm{m}} & \text { M-M half saturation coefficient } \\ \lambda & \text { Lag time } \\ \mathrm{LB} & \text { Luria-Bertani Medium } \\ \mathrm{MICP} & \text { Microbially Induced Calcium Carbonate Precipitation } \\ \mathrm{M}-\mathrm{M} & \text { Michaelis-Menten enzyme kinetics model } \\ \mu_{\max } & \text { Maximum specific growth rate } \\ \mathrm{OD} & \text { Optical Density } \\ \mathrm{OD} & \text { Initial Optical Density } \\ \mathrm{OD}_{\mathrm{st}} & \text { Steady-state Optical Density } \\ \mathrm{R}^{2} & \text { Coefficient of determination } \\ \mathrm{t} & \text { Time variable } \\ \mathrm{V}_{\mathrm{max}} & \text { M-M maximum reaction velocity (rate) }\end{array}$

\section{Acknowledgments}

We wish to thank Adrienne Phillips for a careful edit as well as Dr. Mike Franklin for thoughtful guidance. This work was funded by the National Science Foundation through NSF award No. DMS-0934696 and by Office of Science (BER), Subsurface Biogeochemical Research Program, U.S. Department of Energy through Grant Numbers DE-FG-0209ER64758, DE-FG02-07ER64417 and DE-FG02-09ER64734.

\section{Appendix A. Supplementary data}

Supplementary data to this article can be found online at http:// dx.doi.org/10.1016/j.mimet.2013.06.028.

\section{References}

Andersen, J.B., Sternberg, C., Poulsen, L.K., Bjorn, S.P., Givskov, M., Molin, S., 1998. New unstable variants of green fluorescent protein for studies of transient gene expression in bacteria. Appl. Environ. Microbiol. 64, 2240-2246.

Anderson, R.J., Bendell, D.J., Groundwater, P.W., 2004. Ultraviolet-Visible (UV-Vis) spectroscopy. Organic Spectroscopic Analysis. Royal Society of Chemistry, pp. $7-23$.

Armstrong, R., Ajo-Franklin, J., 2011. Investigating biomineralization using synchrotron based X-ray computed microtomography. Geophys. Res. Lett. 38, L08460.

Bachmeier, K.L., Williams, A.E., Warmington, J.R., Bang, S.S., 2002. Urease activity in microbiologically-induced calcite precipitation. J. Biotechnol. 93, 171-181.

Benini, S., Gessa, C., Ciurli, S., 1996. Bacillus pasteurii urease: a heteropolymeric enzyme with a binuclear nickel active site. Soil Biol. Biochem. 28, 819-821.

Benini, S., Rypniewski, W.R., Wilson, K.S., Miletti, S., Ciurli, S., Mangani, S., 1999. A new proposal for urease mechanism based on the crystal structures of the native and inhibited enzyme from Bacillus pasteurii: why urea hydrolysis costs two nickels. Structure 7, 205-216.

Bosak, T., Newman, D.K., 2005. Microbial kinetic controls on calcite morphology in supersaturated solutions. J. Sediment. Res. 75, 190-199.

Caspi, R., Altman, T., Dreher, K., Fulcher, C.A., Subhraveti, P., Keseler, I.M., Kothari, A., Krummenacker, M., Latendresse, M., Mueller, L.A., Ong, Q., Paley, S., Pujar, A., Shearer, A.G., Travers, M., Weerasinghe, D., Zhang, P., Karp, P.D., 2012. The MetaCyc database of metabolic pathways and enzymes and the BioCyc collection of pathway/genome databases. Nucleic Acids Res. 40, D742-D753.
Ciurli, S., Marzadori, C., Benini, S., Deiana, S., Gessa, C., 1996. Urease from the soil bacterium Bacillus pasteurii: immobilization on Ca-polygalacturonate. Soil Biol. Biochem. 28, 811-817

Clark, S., Francis, P.S., Conlan, X.A., Barnett, N.W., 2007. Determination of urea using high-performance liquid chromatography with fluorescence detection after automated derivatisation with xanthydrol. J. Chromatogr. A 1161, 207-213.

Collins, C.M., Falkow, S., 1990. Genetic analysis of Escherichia coli urease genes: evidence for two distinct loci. J. Bacteriol. 172, 7138-7144.

Cunningham, A.B., Lauchnor, E., Eldring, J., Esposito, R., Mitchell, A.C., Gerlach, R. Phillips, A.J., Ebigbo, A., Spangler, L.H., 2013. Abandoned well $\mathrm{CO}_{2}$ leakage mitigation using biologically induced mineralization: current progress and future directions. Greenhouse Gases Sci. Technol. 3, 40-49.

D'Orazio, S.E., Collins, C.M., 1993. The plasmid-encoded urease gene cluster of the family Enterobacteriaceae is positively regulated by UreR a member of the AraC family of transcriptional activators. J. Bacteriol. 175, 3459-3467.

De Muynck, W., De Belie, N., Verstraete, W., 2010. Microbial carbonate precipitation in construction materials: a review. Ecol. Eng. 36, 118-136.

Decho, A.W., 2010. Overview of biopolymer-induced mineralization: what goes on in biofilms? Ecol. Eng. 36, 137-144.

Dohnalkova, A.C., Marshall, M.J., Arey, B.W., Williams, K.H., Buck, E.C., Fredrickson, J.K., 2011. Imaging hydrated microbial extracellular polymers: comparative analysis by electron microscopy. Appl. Environ. Microbiol. 77, 1254-1262.

Ercole, C., Bozzelli, P., Altieri, F., Cacchio, P., Del Gallo, M., 2012. Calcium carbonate mineralization: involvement of extracellular polymeric materials isolated from calcifying bacteria. Microsc. Microanal. 18, 829-839.

Ferris, F., Stehmeier, L., Kantzas, A., Mourits, F., 1996. Bacteriogenic mineral plugging. J. Can. Pet. Technol. 35, 56-61.

Ferris, F.G., Phoenix, V., Fujita, Y., Smith, R.W., 2003. Kinetics of calcite precipitation induced by ureolytic bacteria at 10 to $20{ }^{\circ} \mathrm{C}$ in artificial groundwater. Geochim. Cosmochim. Acta 68, 1701-1710.

Fidaleo, M., Lavecchia, R., 2003. Kinetic study of enzymatic urea hydrolysis in the $\mathrm{pH}$ range 4-9. Chem. Biochem. Eng. Q. 17, 311-319.

Folkesson, A., Haagensen, J.A.J., Zampaloni, C., Sternberg, C., Molin, S., 2008. Biofilm induced tolerance towards antimicrobial peptides. PLoS One 3, e1891.

Fujita, Y., Ferris, F.G., Lawson, R.D., Colwell, F.S., Smith, R.W., 2000. Calcium carbonate precipitation by ureolytic subsurface bacteria. Geomicrobiol. J. 17, 305-318.

Gompertz, B., 1825. On the nature of the function expressive of the law of human mortality, and on a new mode of determining the value of Life Contingencies. Philos. Trans. R. Soc. Lond. 115, 513-583.

Graf von der Schulenburg, D.A., Pintelon, T.R.R., Picioreanu, C., Van Loosdrecht, M.C.M. Johns, M.L., 2009. Three-dimensional simulations of biofilm growth in porous media. AICHE J. 55, 494-504.

Jahns, T., 1992. Regulation of urea uptake in Pseudomonas aeruginosa. Antonie Van Leeuwenhoek 62, 173-179.

Jahns, T., 1996. Ammonium/urea-dependent generation of a proton electrochemical potential and synthesis of ATP in Bacillus pasteurii. J. Bacteriol. 178, 403-409.

Kim, J.K., Mulrooney, S.B., Hausinger, R.P., 2006. The UreEF fusion protein provides a soluble and functional form of the UreF urease accessory protein. J. Bacteriol. $188,8413-8420$.

Larrainzar, E., O'Gara, F., Morrissey, J.P., 2005. Applications of autofluorescent proteins for in situ studies in microbial ecology. Annu. Rev. Microbiol. 59, 257-277.

Larson, A.D., Kallio, R.E., 1954. Purification and Properties of Bacterial Urease. J. Bacteriol. 68, 67-73.

Lasdon, L.S., Waren, A.D., Jain, A., Ratner, M., 1978. Design and Testing of a generalized reduced gradient code for nonlinear programming. ACM Trans. Math. Softw. 4, 34-50.

Lauchnor, E.G. Schultz, L.N., Bugni, S, Mitchell, A.C. Cunningham, A.B., Gerlach, R., 2013. Bacterially induced calcium carbonate precipitation and strontium coprecipitation in a porous media flow system. Environ. Sci. Technol. 47, 1557-1564.

Mitchell, A.C., Ferris, F.G., 2006. The influence of Bacillus pasteurii on the nucleation and growth of calcium carbonate. Geomicrobiol. J. 23, 213-226.

Mobley, H.L.T., Hausinger, R.P., 1989. Microbial ureases: significance, regulation, and molecular characterization. Microbiol. Rev. 53, 85-108.

Mobley, H.L.T., Island, M.D., Hausinger, R.P., 1995. Molecular-biology of Microbial Ureases. Microbiol. Rev. 59, 451-480.

Morris, N.S., Stickler, D.J., McLean, R.J., 1999. The development of bacterial biofilms on indwelling urethral catheters. World J. Urol. 17, 345-350.

Newman, J.R., Fuqua, C., 1999. Broad-host-range expression vectors that carry the Larabinose-inducible Escherichia coli araBAD promoter and the araC regulator. Gene 227, 197-203.

Phillips, A.J., Lauchnor, E., Eldring, J.J., Esposito, R., Mitchell, A.C., Gerlach, R., Cunningham, A.B., Spangler, L.H., 2013. Potential $\mathrm{CO}_{2}$ leakage reduction through biofilm-induced calcium carbonate precipitation. Environ. Sci. Technol. 47, 142-149.

Riding, R., 2000. Microbial carbonates: the geological record of calcified bacterial-algal mats and biofilms. Sedimentology 47, 179-214.

Riding, R., Liang, L., 2005. Geobiology of microbial carbonates: metazoan and seawater saturation state influences on secular trends during the Phanerozoic. Palaeogeogr. Palaeoclimatol. Palaeoecol. 219, 101-115.

Rodriguez-Navarro, C., Jimenez-Lopez, C., Rodriguez-Navarro, A., Gonzalez-Muñoz, M.T., Rodriguez-Gallego, M., 2007. Bacterially mediated mineralization of vaterite. Geochim. Cosmochim. Acta 71, 1197-1213.

Sar, P., Kazy, S.K., Asthana, R.K., Singh, S.P., 1998. Nickel uptake by Pseudomonas aeruginosa: role of modifying factors. Curr. Microbiol. 37, 306-311.

Schultz, L., Pitts, B., Mitchell, A.C., Cunningham, A.B., Gerlach, R., 2011. Imaging biologically induced mineralization in fully hydrated flow systems. Microsc. Today 19, 12-15. 
Sternberg, C., Christensen, B.B., Johansen, T., Toftgaard Nielsen, A., Andersen, J.B. Givskov, M., Molin, S., 1999. Distribution of bacterial growth activity in flowchamber biofilms. Appl. Environ. Microbiol. 65, 4108-4117.

Stewart, D.J., 1965. The urease activity of fluorescent pseudomonads. J. Gen. Microbiol. 41, 169-174.

Stocks-Fischer, S., Galinat, J.K., Bang, S.S., 1999. Microbiological precipitation of $\mathrm{CaCO}_{3}$ Soil Biol. Biochem. 31, 1563-1571.

Tobler, D.J., Cuthbert, M.O., Greswell, R.B., Riley, M.S., Renshaw, J.C., Handley-Sidhu, S., Phoenix, V.R., 2011. Comparison of rates of ureolysis between Sporosarcina pasteurii and an indigenous groundwater community under conditions required to precipitate large volumes of calcite. Geochim. Cosmochim. Acta 75, 3290-3301.

Vasconcelos, C., McKenzie, J.A., Bernasconi, S., Grujic, D., Tiens, A.J., 1995. Microbial mediation as a possible mechanism for natural dolomite formation at low temperatures. Nature 377, 220-222.

Werner, E., Roe, F., Bugnicourt, A., Franklin, M.J., Heydorn, A., Molin, S., Pitts, B., Stewart P.S., 2004. Stratified growth in Pseudomonas aeruginosa biofilms. Appl. Environ. Microbiol. 70, 6188-6196.
Whiffin, V.S., Van Passen, L.A., Harkes, M.P., 2007. Microbial carbonate precipitation as a soil improvement technique. Geomicrobiol. J. 24, 417-423.

Wilks, J.C., Slonczewski, J.L., 2007. pH of the cytoplasm and periplasm of Escherichia coli: rapid measurement by green fluorescent protein fluorimetry. J. Bacteriol. 189, 5601-5607.

Yoon, J.H., Lee, K.C., Weiss, N., Kho, Y.H., Kang, K.H., Park, Y.H., 2001. Sporosarcina aquimarina sp. nov., a bacterium isolated from seawater in Korea, and transfer of Bacillus globisporus (Larkin and Stokes 1967), Bacillus psychrophilus (Nakamura 1984) and Bacillus pasteurii (Chester 1898) to the genus Sporosarcina as Sporosarcina globispora comb. nov., Sporosarcina psychrophila comb. nov. and Sporosarcina pasteurii comb. nov., and emended description of the genus Sporosarcina. Int. J. Syst. Evol. Microbiol. 51, 1079-1086.

Zhang, T., Klapper, I., 2010. Mathematical model of biofilm induced calcite precipitation. Water Sci. Technol. 61, 2957-2964.

Zhang, S., Li, D.X., Tian, K., Bai, Y., Zhang, H.K., Song, C.J., Qiao, M.Q., Kong, D.L., Yu, Y.T., 2009. Development of a recombinant ureolytic Lactococcus Lactis for urea removal. Artif. Cells Blood Substit. Immobil. Biotechnol. 37, 227-234.

Zwietering, M.H., Jongenburger, I., Rombouts, F.M., Van 'T Riet, K., 1990. Modeling of the bacterial growth curve. Appl. Environ. Microbiol. 56, 1875-1881. 